\title{
Vandalism in the system of statutory evaluation: a comparative analysis of the Russian and German legislation
}

\author{
Olesya Aleksandrovna Blinova ${ }^{1^{*}}$, Irina Vladimirovna Deviatovskaia ${ }^{2}$, Marina Rashitovna \\ Babikova $^{3}$, and Yury Sergeevich Isaev $^{4}$ \\ ${ }^{1}$ FSPFEIHE Ural State Pedagogical University, Institute of Psychology, Ekaterinburg, Russia \\ ${ }^{2}$ FSPFEIHE Ural State Pedagogical University, Institute of Social Education, Ekaterinburg, Russia \\ ${ }^{3}$ FSPFEIHE Ural State Pedagogical University, Institute of Philology and Intercultural \\ Communication, Ekaterinburg, Russia \\ ${ }^{4}$ Eberhard Karl University of Tübingen, Faculty of Law, Tuebingen, Germany
}

\begin{abstract}
The article presents an experience of comparing the articles of the Criminal Code of the Russian Federation and of the Federal Republic of Germany (Strafgesetzbuch), aimed at protecting social interaction and public order from vandalism. The purpose of the given comparison was an attempt to form a holistic treatment of the phenomenon of vandalism from the point of view of statutory evaluation. To make the comparison, a comparative legal analysis of the relevant norms was selected as a tool. As a result, the authors have identified the similarities and differences in the structure of legal norms, in the terminology, the existence of related norms protecting against encroachment on public order - those similar to antivandal measures, the specificity of public relations, as well as personal property rights. The prospect of further research on the legal status of vandalism in different countries has been outlined.

Keywords: vandalism, criminal law, Criminal Code of the Russian Federation, Strafgesetzbuch
\end{abstract}

\section{Introduction}

lawyers, psychologists, pedagogues, and other scholars view vandalism as a form of deviant behaviour, the conduct that runs counter to institutional expectations [1].

Although vandalism is traditionally condemned, the number of cases pleaded under Art. 214 of the Criminal Code of the Russian Federation (CC RF) is so insignificant that they usually do not appear in the reports of the Ministry of Internal Affairs, while the punishment for this type of crime is minor [2]. For instance, 193 cases were considered by courts in 2019 under Art. 214, of them 145 cases under Part 1 and 48 cases under Part 2 of the said Article. All the defendants under this article were found guilty, with the exception of 53 persons who were found insane and thus were sentenced to coercive measures. Nevertheless, one should note certain leniency of the passed judgements: for instance, just over 22 per cent of the

\footnotetext{
* Corresponding author: olesyablinova79@yandex.ru
} 
accused were sentenced to imprisonment or restraint of liberty, while over 70 per cent of all sentences comprised penalties, correctional and forced labour [3].

In Germany, vandalism includes, in the first place, damage to property: the destruction of bus stops, shop windows, damage to cars, etc. According to the 2019 report of the Federal Criminal Police Office (Bundeskriminalamt), 563,062 cases were registered under Article 304 , which accounts for $10.4 \%$ of all registered crimes $[4,5]$. Naturally, not all of the cases are manifestations of vandalism. For instance, "other damage to property in the streets, sidewalks and public areas" " was recorded in 137,748 cases, which makes almost $22 \%$ of the total figure.

The criminal codes of Russia and Germany $\left(\mathrm{StGB}^{2}\right)$ have a lot in common: origination from the Romano-Germanic law; reliance on formal, documented norms; the same structure in terms of corpus delicti; the same sources of criminal law; distributed nature, i.e., the presence of other norms similar to those in respect of vandalism; common principles such as legality, justice, humanism, etc. [6]. Vandalism in Germany is considered exclusively as a criminal offence, which is regulated by $\S 303$ of the StGB [7].

The reference to the works of Russian scholars shows that the study of vandalism is dominated by socio-psychological focus [8-10], with this phenomenon regarded as a form of deviant and destructive behaviour. Jurists' works on vandalism are few. The research of the German criminal law is presented in the works by Serebrennikova [11], Inogamova-Khegai [12], Zhalinskii [13]; however, the problem of vandalism is outlined in them just tenuously. In the German-language literature, studies of vandalism as an offence are scarce [14-16].

In this regard, as well as due to the absence of such studies in the Russian and German jurisprudence, the authors deem it relevant to make a comparative legal analysis of the legislation of the RF and the FRG, as well as of the judicial practice of these countries, in order to identify, on the basis of certain criteria, similarities and differences in the said states' attitudes to acts of vandalism.

\section{Methods}

The basic tool of the research was comparative legal analysis of the Russian and German laws on vandalism, according to the following criteria:

- disposition;

- objective aspect;

- subjective aspect;

- purpose and motives;

- sanctions.

\section{$3 \quad$ Results}

Following the implemented comparative legal analysis of relevant articles of the CC RF and StGB FRG, the following results were obtained.

Table $\square$. Results of comparative legal analysis.

\begin{tabular}{|l|l|l|}
\hline Criteria & Russian Federation & Federal Republic of Germany \\
\hline
\end{tabular}

\footnotetext{
1 "sonstige Sachbeschädigung auf Straßen, Wegen oder Plätzen"

${ }^{2}$ StGB (Strafgesetzbuch)
} 


\begin{tabular}{|c|c|c|}
\hline Disposition & $\begin{array}{l}\text { subject of crime: befoulment } \\
\text { and destruction of buildings, or } \\
\text { damage to property in public } \\
\text { areas }\end{array}$ & $\begin{array}{l}\text { subject of crime: damage to } \\
\text { public facilities or public } \\
\text { domain items }\end{array}$ \\
\hline Objective aspect & $\begin{array}{l}\text { actual object: public order; } \\
\text { additional object }- \text { public } \\
\text { relations }\end{array}$ & $\begin{array}{l}\text { actual object: property } \\
\text { relations; additional object - } \\
\text { public order }\end{array}$ \\
\hline Subjective aspect & \multicolumn{2}{|l|}{ premeditated crime } \\
\hline $\begin{array}{l}\text { Motives and } \\
\text { purpose }\end{array}$ & $\begin{array}{l}\text { difficult to define due to the } \\
\text { irrational nature of the crime }\end{array}$ & $\begin{array}{l}\text { purpose - causing harm; } \\
\text { the motive can be personal, but } \\
\text { it can also be irrational }\end{array}$ \\
\hline \multirow[t]{2}{*}{ Sanction } & \multicolumn{2}{|l|}{$\begin{array}{l}\text { minimum penalty - a fine, } \\
\text { maximum penalty - imprisonment }\end{array}$} \\
\hline & imprisonment for up to 3 years & imprisonment for up to 5 years \\
\hline
\end{tabular}

\section{Discussion}

Vandalism as a crime per se has been regulated by the criminal legislation of the Russian Federation since 1996, when the current Criminal Code was adopted. Article 214 addresses vandalism as a separate offence; it states that vandalism "is befoulment of buildings or other structures, damage to property in public transport or in other public areas" or "the same acts committed by a group of persons, as well as on the grounds of political, ideological, racial, national or religious hatred or enmity, or based on hatred or enmity in relation to a particular social group" [17].

The concept of "vandalism" is not used directly in the current StGB FRG in force as of November 13, 1998. However, a number of criminal acts involving damage or destruction of property in public areas qualify for vandalism to some extent. Paragraph 304 states that damage or destruction of facilities serving as objects of veneration in the territory of the state or a religious society, as well as items intended for divine service, or tombstones, public and natural objects of art, science, crafts kept in public places or publicly exhibited, as well as objects that cater for public needs or used to decorate roads, squares, and structures, is punishable by imprisonment or a pecuniary penalty [7]. Further on, $\$ 305$ discloses liability for destruction of structures, railways, cars, streets, etc. [7].

The disposition of Art. 214 of the CC RF defines the following deeds that encroach on public order and social relations as vandalism:

- befoulment of buildings and structures, regardless of the form of ownership;

- damage to property in public transport and in other public areas.

According to the disposition of the German criminal-law standards, the principal (direct) object of offence is encroachment on property relations, while public order is regarded as a second-priority object. The subject of crime in $\S \S 304-305$ of StGB FRG is presented more extensively than in Art. 214, Part 1, of the CC RF. It includes not only public domain objects but also objects of worship. Thus, the criminal deeds under these articles and those considered as vandalism are the same. 
One should note, analyzing the objective aspect of the criminal act, that the term "befoulment" is absent from $\$ 304$ of StGB FRG, but it follows from the meaning of the law or is partially implied [18]; thus, an offence regulated under $\$ 304$ and $\S 305$ of StGB FRG is similar in its objective features to vandalism, as defined by Art. 214 of the CC RF.

The sanction under Article 214 assumes punishment to range from penalty to imprisonment of up to three years. Part 1 of this article provides for a more lenient punishment - either a penalty or correctional or forced labour, or arrest for up to three months, while Part 2 supposes not only a fine and forced work but also restraint of freedom or imprisonment for up to three years. A similar sanction can be found in $\S \S 304-305$ of StGB FRG. Whereas Art. 214 of the CC RF clearly defines the penalty amount, this is not envisaged in the StGB FRG. The sanction in the form of imprisonment is clearly specified only in $\S 305$ - up to 5 years; the same in the CC RF - up to three years. Analysing the articles considering acts of vandalism in the criminal norms of Russia and Germany, one can see that the Russian legislation distinguishes vandalistic deeds in terms of severity, applying different sanctions to them. At the same time, it is difficult to conclude from the German norms whether a convicted person would be fined or imprisoned, for no due distinction of cases. The Russian Criminal Code is more flexible in fixing the punishment for vandalism, which makes it possible to impose a measure of restraint consistent with the severity of the committed act.

Vandalism is often confused with hooliganism; the latter is regulated by Art. 213 of the CC RF. To avoid this confusion, it is necessary to refer to the Resolution of the Plenum of the Supreme Court No. 45 dated November 15, 2007 [19] which specifies the deeds covered by Article 213. However, it is quite difficult to find a similar norm in StGB FRG. Comparing the notion of hooliganism in Russia and Germany, one can turn to $\$ 125$ which treats hooliganism as offence against public order, though directed, in the first place, against an individual and his property, and, therefore, not viewed as vandalism.

Drawing inscriptions or patterns having a positive content does not constitute an offence, is not treated as vandalism, and is not regulated by Art. 214. Such actions are covered by Art. 167 of the CC RF or Art. 7.17 of the Administrative Offence Code of the Russian Federation.

Destruction of gravestones or befoulment of burials, being associated in the mind of ordinary people with vandalism, is not treated as such; the above actions are regulated by Art. 244 of the CC RF. Destruction or befoulment of national monuments is within the domain of Art. 243 of the CC RF. As concerns desecration of monuments to Soviet military leaders in European countries, a special federal law was adopted - No. 112-FZ as of April 7, 2020 - which aims at the preservation of military graves and memorials [20]. A similar content can be observed in $\S 68$ and $\S 314$ of StGB FRG [Criminal Code of FRG] [7].

Unlike the CC RF, the German StGB protects religious practices, religious buildings and places of worship, as well as faith in general, against vandalism ( $\S \S 166-168)$ : $\$ 166$ Beschimpfung von Bekenntnissen ("Insult to church and faith"); §167 Störung der Religionsausübung (“Obstruction to performance of religious rites") [7].

Summing up, one can note that although the interpretation of the concept of "vandalism" is quite constrained in the Russian criminal law, being in fact absent in the German law, both criminal codes provide for a differing, more specific wording in respect of acts of vandalism, depending on state significance and cultural value of the affected object, and prescribe penalties commensurate with the gravity of the committed deed.

\section{Conclusion}

As a result of comparative legal analysis of the CC RF and StGB FRG, the following conclusions were made: 
1. The rules of law covering vandalism have a similar disposition, subjective aspect, purpose, motive, and sanction in the criminal law of both countries. The objective aspect is the only difference.

2. In both countries, the age of prosecution for committing vandalistic deeds is the same -14 years old.

3. Both criminal codes are characterised by an extended treatment of acts of vandalism, their qualification, and due punishment.

4. Russia and Germany differ in the principles of the account of crimes relating to vandalism.

The obtained results can be used by specialists for studying specific approaches to statutory evaluation of vandalistic deeds and the legal status of vandalism in different countries.

The research was executed with the support of the Russian Science Foundation grant, project No. 1718-01278.

\section{References}

1. A. Cohen, Issledovanie problem sotsialnoi dezorganizatsii i otklonyayushchegosya povedeniya [The study of social disorganisation and deviant behaviour], in Sotsiologiya segodnya [Sociology today], 519-550 (Progress, Moscow, 1965). Accessed on: March 22, 2021. [Online]. Available: https://nauchi.livejournal.com/12701.html

2. Ministry of Internal Affairs of the Russian Federation, Kratkaya kharakteristika sostoyaniya prestupnosti v Rossiiskoi Federatsii za yanvar - dekabr 2019 goda [Brief description of the delinquency profile in the Russian Federation in January - December 2019]. Accessed on: March 22, 2021. [Online]. Available: https: //xn--b1aew.xn-p1ai/reports/item/19412450/

3. Sudebnaya statistika RF [Judicial Statistics of the Russian Federation] (2020). Accessed on: March 22, 2021. [Online]. Available: http://stat.xn----7sbqk8achja.xn-p1ai/stats/ug/t/14/s/17

4. Poliseiliche Kriminalstatistik 2019. Ausgewählte Zahlen im Überblick (2019) Accessed on: March 22, 2021. [Online]. Available: https://www.bmi.bund.de/SharedDocs/downloads/DE/publikationen/themen/sicherheit/ pks-2019.pdf?_blob=publicationFile \&v $=4$

5. PKS-Jahrbuch (2019). Accessed on: March 22, 2021. [Online]. Available: https://www.bka.de/DE/AktuelleInformationen/StatistikenLagebilder/PoliseilicheKrimi nalstatistik/PKS2019/PKSJahrbuch/pksJahrbuch_node.html

6. T.R. Sabitov, Russian Law: Education, Practice, Science, 6, 27-34 (2019). https://doi.org/10.34076/2410-2709-6-27-34

7. Strafgesetzbuch (StGB) Bundesrepublik Deutschland. In der Fassung der Bekanntmachung vom 13.11.1998 (BGBl. I S. 3322) Stand: 01.09.2020 aufgrund Gesetzes vom 15.11.2019 (BGBl. I S. 1604). Accessed on: March 22, 2021. [Online]. Available: https://dejure.org/gesetze/StGB

8. L.S. Vatova, Sotsialno-psikhologicheskie osnovaniya molodezhnogo vandalizma i ego profilaktika [Socio-psychological foundations of adolescent and post-teen vandalism and its prevention] (Narodnoe obrazovanie, Moscow, 2007)

9. I.V. Vorobieva, O.V. Kruzhkova, Psikhologiya vandalnogo povedeniya [Vandalistic behaviour psychology] (Ural State Pedagogical University, Ekaterinburg, 2015) 
10. V.D. Mendelevich, Psikhologiya deviantnogo povedeniya: uchebnoe posobie [Psychology of Deviant Behaviour: Textbook] (MED-press, Moscow, 2011)

11. A.V. Serebrennikova, Interactive Science, 7, 59-62 (2016). https://doi.org/10.21661/r113101

12. L.V. Inogamova-Khegai, Mezhdunarodnoe ugolovnoe pravo: uchebnoe posobie dlya magistrantov [International Criminal Law: a Textbook for Master Course Students] (Prospekt, Moscow, 2015)

13. E. Zhalinskii, Sovremennoe nemetskoe ugolovnoe pravo [Modern German criminal law] (TK Welby, Prospekt, Moscow, 2006)

14. T. Fischer, O.G. Schwarz, E. Dreher, H. Troendle, Strafgesetzbuch mit Nebengesetzen (C.H. Beck, München, 2019)

15. W. Joecks, M. Klaus, Münchener Kommentar zum Strafgesetzbuch (C.H. Beck, München, 2020)

16. H. Hirtenlehner, H. Leitgöb, K. Stiebellehner, A.Birklbauer, J. Bacher, Zeitschrift für Jugendkriminalrecht und Jugendhilfe, 30(1), 121-132 (2019)

17. Ugolovnyi kodeks Rossiiskoi Federatsii ot 13.06.1996 No. 63-FZ (red. ot 27.10.2020) [Criminal Code of the Russian Federation No. 63-FZ (as amended on October 27, 2020)] (1996, June 13). Accessed on: March 22, 2021. [Online]. Available: http://www.consultant.ru/document/cons_doc_LAW_10699/

18. V.G. Pavlov, Bulletin of St. Petersburg Academy of Law, 4(25), 95-100 (2014)

19. Postanovlenie Plenuma Verkhovnogo Suda ot 15 noyabrya 2007 g. No. 45 “O sudebnoi praktike po ugolovnym delam o khuliganstve i inykh prestupleniyakh, sovershennykh iz khuliganskikh pobuzhdenii" [Resolution of the Plenum of the Supreme Court No. 45 "On judicial practice under criminal cases of hooliganism and other offences committed from molester motives"] (2007, November 15). Accessed on: March 22, 2021. [Online]. Available: http://www.consultant.ru/document/cons_doc_LAW_72601/

20. Federalnyi zakon ot 07.04.2020 No. 112-FZ "O vnesenii izmenenii v Ugolovnyi kodeks Rossiiskoi Federatsii i Ugolovno-protsessualnyi kodeks Rossiiskoi Federatsii” [Federal Law No. 112-FZ "On Amendments to the Criminal Code of the Russian Federation and the Criminal Procedure Code of the Russian Federation"] (2020, April 7). Accessed on: March 22, 2021. [Online]. Available: http://www.consultant.ru/law/hotdocs/61497.html/ 